\title{
IDENTIFIKASI NILAI-NILAI PENDIDIKAN ISLAM DALAM PEMBERDAYAAN MASYARAKAT PADA PNPM MANDIRI
}

\author{
Bekti Taufiq Ari Nugroho dan Mustaidah \\ IAIN Salatiga, Jawa Tengah, Indonesia \\ bektitaufiq65@gmail.com
}

\begin{abstract}
Abstrak
In this reform era, many people started questioning about community development and empowerment. Based on the experience that happened, it shows that so far Indonesia which is one of the developing countries has not been liberated from poverty, underdevelopment and unemployment. Basically these conditions were rejected by bumans but difficult to be avoided. In a study on the public course, is inseparable from the values of Islamic education. At the present time, a lot of learning done through non-formal educations with a variety of models and forms of learning. For example: learning programs for the community empowerment through PNPM Mandiri. The purpose of this study was to know the values of Islamic education which is contained in the PNPM Mandiri. This study is a literature research by using document review methods in collecting descriptive data. The data collection is done by collecting data from the literature on community empowerment and PNPM Mandiri. Because the data is in the form of descriptive, so
\end{abstract}


the techniques used to analyze the data is contents analysis, to analyze the contents of the obtained data. From the results of this study concluded that in PNPM Mandiri teach values of Islamic education, these values are the values of khuluqiyah (honest, trustworthy, sincere, and fair) and amaliyah values (equality, unity in diversity, democracy, transparency, participation). All values are in line with the basic principles of community empowerment.

Keywords: Islamic Education Values, Empowerment, PNPM Mandiri.

\section{Abstrak}

Di era reformasi seperti sekarang banyak pihak mulai mempertanyakan tentang pembangunan dan pemberdayaan masyarakat. Berdasarkan pengalaman yang terjadi menunjukean bahwa selama ini Indonesia yang merupakan salah satu negara berkembang yang belum terbebas dari kemiskinan, keterbelakangan dan pengangguran. Pada dasarnya kondisi tersebut merupakan sesuatu yang ditolak manusia tetapi sulit untuk dibindarkan. Dalam pembelajaran pada masyarakat tentunya tidak terlepas dari nilai-nilai pendidikan Islam. Pada saat sekarang ini banyak pembelajaran yang dilaksanakan melalui pendidikanpendidikan non formal dengan berbagai macam model maupun bentuk, misalnya pembelajaran bagi masyarakat dengan program pemberdayaan yaitu melalui PNPM Mandiri. Tujuan dari penelitian ini adalah untuk mengetahui nilai-nilai pendidikan Islam apa saja yang terkandung dalam PNPM Mandiri. Penelitian ini merupakan penelitian kepustakaan yang menggunakan metode telaah dokumen dalam mengumpulkan data deskriptif. Pengumpulan data dilakukan dengan menghimpun data dari berbagai literatur tentang pemberdayaan masyarakat dan PNPM Mandiri. Karena datanya berupa deskriptif, maka teknik yang digunakan untuk menganalisis data adalah content analysis yaitu menganalisis isi dari data yang diperoleh. Dari hasil penelitian dapat disimpulkan bahwa dalam PNPM Mandiri mengajarkan nilai-nilai pendidikan Islam, nilai-nilai tersebut adalah nilai khuluqiyah (jujur, amanah, ikhlas, adil) dan nilai amaliyah (kesetaraan, kesatuan dalam keberagaman, demokrasi, transparansi, partisipasi). Semua nilai-nilai tersebut sejalan dengan prinsip dasar dalam pemberdayaan masyarakat.

Kata kunci: Nilai-Nilai Pendidikan Islam, Pemberdayaan Masyarakat, PNPM Mandiri. 


\section{A. Pendahuluan}

Pembangunan negara berkembang selalu dilatarbelakangi oleh permasalahan keterbelakangan, kemiskinan, dan pengangguran. ${ }^{1}$ Krisis ekonomi pada pertengahan 1997 menyebabkan peningkatan jumlah penduduk miskin menjadi meningkat. Dampak keseluruhan yang dirasakan oleh masyarakat Indonesia adalah bertambahnya jumlah rumah tangga miskin di pedesaan maupun perkotaan, rusaknya struktur sosial yang disebabkan hilangnya pekerjaan dan hilangnya kemampuan untuk memenuhi kebutuhan. Namun, seiring berjalannya waktu dan membaiknya perekonomian, jumlah penduduk miskin mengalami penurunan pada Agustus 1999 baik yang berada di daerah perkotaan maupun pedesaan. ${ }^{2}$

Kemiskinan sesungguhnya merupakan suatu kondisi yang ditolak oleh manusia, tetapi kenyataanya sulit untuk dihindarkan. Berdasarkan pengalaman yang terjadi menunjukkan bahwa selama ini Indonesia belum pernah terbebas dari kemiskinan. ${ }^{3}$ Upaya memperbaiki kualitas hidup manusia terutama pada lapisan masyarakat bawah, mulai mendapat perhatian setelah teridentifikasi adanya kelemahan dari paradigma pertumbuhan yang memiliki "economic bias". Upaya tersebut secara tidak langsung melahirkan konsep pembangunan sosial yang dijiwai paradigma kebutuhan dasar untuk kesejahteraan atau bantuan bagi orang miskin. ${ }^{4}$ Pada prinsipnya kemiskinan bukanlah sekedar fenomena, akan tetapi lebih merupakan proses yang tereduksi akibat kerentanan yang melanda pada banyak faktor.

${ }^{1}$ Randy, R.W dan Riant, N.D, Manajement Pemberdayaan: Sebuah penga tar dan Panduan Untuk Pemberdayaan Masyarakat, Jakarta: Elex Media Komputindo, 2007, hlm. 77.

${ }^{2}$ Tim Crescent, Menuju Masyarakat Mandiri: Pengembangan Sistem Keterjam nan Sosial, Jakarta: PT. Gramedia Pustaka Utama, 2003, hlm. 1.

${ }^{3}$ Ambar Teguh, S, Kemitraan dan Model Model Pemberdayaan, Yogyakarta: Gava Media, 2004, hlm. 3.

${ }^{4}$ CSIS, Pemberdayaan Masyarakat Lapis Bawah Center for setrategis and Inte national Studies/ jurnal, 1997, hlm. 42. 
Dalam tiga dasawarsa terakhir ini, masyarakat kita mengalami perubahan sosial yang cukup pesat. Tetapi sayangnya perubahan tersebut tidak menghadirkan kemandirian dan kesejahteraan seperti masih banyaknya masyarakat miskin yang hanya selalu mengharapkan bantuan dari orang lain dan adanya pihak yang berkuasa telah berlaku yang tidak adil, tidak demokratis, dan memusuhi siapa yang di anggap menghalangi kehendaknya. Dengan keadaan yang demikian dalam era reformasi seperti sekarang banyak pihak mulai mempertanyakan kembali kebijaksanaan pembangunan dan pemberdayaan masyarakat. ${ }^{5}$ Akan tetapi, beberapa literatur menyebutkan bahwa konsep pemberdayaan sudah lahir sejak revolusi industri atau ada juga yang menyebut sejak lahirnya eropa modern pada abad 18 atau zaman renaissance, yaitu ketika orang mulai mempertanyakan diterminisme keagamaan.

Fokusnya pemberdayaan adalah lokalitas, karena civil society lebih siap diberdayakan lewat isu-isu lokal. Konsep pemberdayaan merupakan hasil interaksi ideologis maupun praktis. Pemberdayaan mengandung konteks pemihakan kepada masyarakat yang berada di bawah garis kemiskinan. ${ }^{6}$ Program pemberdayaan masyarakat di nilai sebagai salah satu strategi yang mampu menanggulangi kemiskinan.

Pemberdayaan masyarakat sendiri muncul 15 tahun belakangan dan memasuki tahun 2000-an yang telah banyak mendominasi wacana kebijakan publik. Permasalahan kemiskinan yang cukup kompleks membutuhkan intervensi semua pihak secara bersama dan terkoordinasi.

Untuk meningkatkan efektivitas upaya penanggulangan kemiskinan dan penciptaan lapangan kerja, maka pemerintah memutuskan meluncurkan Program Nasional Pemberdayaan

${ }^{5}$ Sunyoto Usman, Pembangunan dan Pemberdayaan Masyarakat, Yogyakarta: Pustaka Pelajar, 2008, hlm. iv.

${ }^{6}$ Gunawan Sumodiningrat, Pemberdayaan Sosial, Jakarta: PT. Kompas M dia Nusantara, 2007, hlm. 28-29. 
Masyarakat (PNPM) Mandiri mulai tahun 2007 dan sebagai salah satu program penanggulangan kemiskinan di perkotaan. ${ }^{7}$ Kondisi kelembagaan masyarakat yang tidak mengakar, tidak representatif dan tidak dapat di percaya pada umumnya tumbuh subur dalam situasi perilaku atau sikap masyarakat yang belum berdaya. Ketidakberdayaan masyarakat dalam menyikapi dan menghadapi situasi yang ada di lingkungannya, yang pada akhirnya mendorong sikap masa bodoh, tidak peduli, tidak percaya diri, mengandalkan bantuan pihak luar untuk mengatasi masalahnya, tidak mandiri, serta memudarnya orientasi moral dan nilai-nilai luhur dalam kehidupan bermasyarakat. $^{8}$

Menurut PNPM Mandiri, pendekatan yang lebih efektif untuk mewujudkan proses perubahan perilaku masyarakat adalah melalui pendekatan pemberdayaan atau proses pembelajaran masyarakat dan penguatan kapasitas untuk mengedepankan peran pemerintah daerah dalam mengapresiasi dan mendukung kemandirian masyarakatnya.

Oleh sebab itu, dengan pandangan dan program melalui PNPM Mandiri sebagai lembaga masyarakat diharapkan tidak ada lagi kelompok masyarakat yang masih terjebak dalam lingkaran kemiskinan. Pada dasarnya PNPM Mandiri sebagai program pemberdayaan masyarakat berbasis nilai, memiliki prinsip dasar yaitu pemberdayaan manusia seutuhnya untuk menumbuhkan kepedulian, kerelawanan dan perilaku yang berpihak pada masyarakat yang miskin dengan dilandasi keikhlasan. Di samping itu, PNPM Mandiri juga berlandaskan nilai-nilai luhur kemanusiaan yang positif yang mana nilai-nilai tersebut secara tidak langsung mengajarkan pendidikan pada masyarakat. Oleh sebab itu peneliti ingin mengetahui nilai-nilai luhur yang melandasi pelaksanaan PNPM Mandiri sebagai nilai pendidikan Islam.

${ }^{7}$ DPU DirJen, Petunjuk Pelaksanaan PNPM Mandiri P2KP, Jakarta: Cipta Karya, 2007, hlm. 18.

${ }^{8}$ DPU DirJen, Pedoman Umum P2KP 3, Jakarta: Cipta Karya, 2005, hlm. 2 . 
Dengan menggunakan penelitian library reseach, masalah yang timbul dalam penelitian ini adalah nilai-nilai pendidikan Islam apa saja yang terkandung dalam PNPM Mandiri sebagai salah satu program pemberdayaan masyarakat dalam pengentasan kemiskinan. Sedangkan tujuan dalam penulisan artikel ini adalah untuk mengetahui nilai-nilai pendidikan Islam apa saja yang terkandung dalam PNPM Mandiri.

Adapun manfaat yang ingin dicapai adalah dalam hasil penelitian ini diharapkan hasilnya menjadi sumbangsih dan memperkaya khasanah pemikiran ke-Islaman pada umumnya dan bagi masyarakat khususnya. Hasil penelitian ini diharapkan dapat bermanfaat sebagai bahan pertimbangan bagi masyarakat dalam memberikan atau melaksanakan suatu pendidikan baik itu melalui lembaga formal, informal maupun non formal.

\section{B. Pembahasan}

\section{Pengertian Nilai-Nilai Pendidikan Islam}

Menurut Burbecher, nilai dibedakan dalam dua bagian yaitu nilai instrinsik yang di anggap baik, tidak untuk sesuatu yang lain, melainkan di dalam dirinya sendiri) dan nilai instrumental (nilai yang di anggap baik karena bernilai untuk yang lain." Nilai menurut Abu Ahmadi dan Noor Salimi, ${ }^{10}$ adalah suatu seperangkat keyakinan atau perasaan yang diyakini sebagai suatu identitas yang memberikan corak khusus kepada pola pemikiran, perasaan, keterikatan, maupun perilaku. Sedangkan menurut Hamid Darmadi, ${ }^{11}$ mengemukakan nilai atau value termasuk bidang kajian tentang filsafat. Istilah nilai dalam bidang filsafat di pakai untuk menunjukkan kata benda abstrak yang artinya

9 Jalaludin \& Abdullah Idi, Filsafat Pendidkan Manusia, Jogjakarta: ArRuzz Media, 2007, hlm. 137.

${ }^{10}$ A.Ahmadi, Nor S, MKDU Dasar Dasar Pendidikean Agama Islam Untuk. Perguruan Tinggi, Jakarta: Bumi Aksara, 1991, hlm. 667.

${ }^{11}$ Hamid Darmadi, Dasar konsep Pendidikan Moral, Landasan Konsep Dasar dan Implementasi, Bandung: Alfabeta, 2007, hlm. 67. 
"keberhargaan" atau kebaikan, dan kata kerja yang artinya suatu tindakan kejiwaan tertentu dalam menilai atau melakukan penilaian.

Adapun pengertian pendidikan Islam sebagaimana yang telah dijelaskan di atas yaitu sebuah proses yang dilakukan unuk menciptakan manusia-manusia seutuhnya, beriman dan bertaqwa kepada Tuhan serta mampu mewujudkan eksistensinya sebagai khalifah Allah di muka bumi, yang berdasarkan pada ajaran AlQuran dan Sunnah. ${ }^{12}$

Dari uraian di atas mengenai pengertian nilai dan pendidikan Islam, maka dapat disimpulkan bahwa nilai-nilai pendidikan Islam adalah suatu seperangkat keyakinan atau perasaan dalam diri manusia yang sesuai dengan norma dan ajaran Islam untuk menciptakan insan kamil (manusia sempurna).

Sebagaimana yang telah dijelaskan di atas mengenai nilai-nilai pendidikan Islam, maka sesungguhnya Al-Quran pun memuat nilai-nilai yang menjadi acuan dalam pendidikan Islam. Nilai tersebut terdiri atas tiga pilar utama, yaitu: nilai I'tiqodiyah, nilai Khuluqiyah, dan nilai Amaliyah. ${ }^{13}$

\section{a. Nilai I'tiqodiyah}

Nilai I'tiqodiyah ini biasa di sebut dengan aqidah. ${ }^{14}$ Nilai I'tiqodiyah yaitu nilai yang berkaitan dengan pendidikan keimanan seperti percaya kepada Allah, Malaikat, Kitab, Rasul, Hari Akhir, dan takdir yang bertujuan untuk menata kepercayaan individu.

Islam berpangkal pada keyakinan tauhid, yaitu keyakinan tentang wujud Allah, tak ada yang menyamai-Nya,baik sifat maupun perbuatan. Pernyataan tauhid paling singkat adalah bacaan tahlil. Dalam penjabarannya aqidah berpokok pada ajaran

${ }^{12}$ Armai Arief, Pengantar ilmu dan metodologi pendidikan islam, Jakart: Cip tat Pers, 2002, hlm. 3.

${ }^{13}$ Abdul Mujib dan Jusuf Mudzakir, Ilmu Pendidikan Islam, Jakarta: Ke cana Prenada Media, 2006, hlm. 36.

${ }^{14}$ Zakiah Daradjat, Ilmu Pendidikan Islam, Jakarta: Bumi Aksara, 2004, hlm. 19. 
yang tercantum dalam rukun iman, yaitu iman kepada Allah, iman kepada Malaikat-Malaikat Allah, iman kepada Kitab-Kitab Allah, iman kepada Rasul-Rasul Allah, iman kepada hari akhir, iman kepada takdir.

\section{a. Nilai Khuluqiyah}

Nilai Khuluqiyah yaitu ajaran tentang hal yang baik dan hal yang buruk, yang menyangkut tingkah laku dan perbuatan manusia. Akhlak biasa di sebut dengan moral. ${ }^{15}$ Akhlak ini menyangkut moral dan etika yang bertujuan untuk membersihkan diri dari perilaku yang tercela dan menghiasi diri dengan perilaku terpuji.

Apabila seseorang mempunyai perilaku dan perangai yang baik, maka boleh dikatakan bahwa dia mempunyai akhlak yang baik. Begitupun sebaliknya, jika seseorang mempunyai perilaku dan perangai yang buruk, maka boleh dikatakan bahwa dia mempunyai akhlak yang buruk. Nilai ini meliputi tolong menolong, kasih sayang, syukur, sopan santun, pemaaf, disiplin, menepati janji, jujur, tanggung jawab dan lain-lain.

\section{a. Nilai Amaliyah}

Nilai Amaliyah yaitu yang berkaitan dengan pendidikan tingkah laku sehari-hari baik yang berhubungan dengan:

1) Pendidikan Ibadah

Pendidikan ini memuat hubungan antara manusia dengan Allah, seperti salat, puasa, zakat, haji, dan nazar, yang bertujuan untuk aktualisasi nilai 'ubudiyah. ${ }^{16}$ Nilai ibadah ini biasa kita kenal dengan rukun Islam, yaitu syahadat, salat, puasa, zakat, dan haji.

${ }^{15}$ H. M. Arifin, Ilmu Pendidikan Islam Sekolah: Suatu Tinjauan Teoritis dan Praktis Berdasarkan Pendekatan Interdisipliner, Jakarta: Bumi Aksara, 2000, hlm. 57

${ }^{16}$ Abdul Mujib dan Jusuf Mudzakir, Ilmu Pendidikan Islam, ..., Ibid, hlm. 36. 
2) Pendidikan Muamalah

Pendidikan ini memuat hubungan antar sesama manusia baik secara individu maupun institusional. ${ }^{17}$ Bagian ini terdiri atas:

1) Pendidikan Syakhshiyah, perilaku individu seperti masalah perkawinan, hubungan suami istri dan keluarga serta kerabat dekat, yang bertujuan untuk membentuk keluarga sakinah dan sejahtera.

2) Pendidikan Madaniyah, perilaku yang berhubungan dengan perdagangan seperti upah, gadai, kongsi, dan sebagainya yang bertujuan untuk mengelola harta benda atau hak-hak individu.

\section{Pengertian Pemberdayaan Masyarakat}

Dalam Ambar Teguh, ${ }^{18}$ menyatakan bahwa pemberdayaan mengandung dua arti:

1. To give power or authority, meliputi pemberian kekuasaan, mengalihkan atau mendelegasikan otoritas kepada pihak yang kurang atau belum berdaya.

2. To give abilityto or enable yaitu memberikan kemampuan atau keberdayaan serta memberikan peluang kepada pihak lain untuk melakukan sesuatu.

Jadi pada dasarnya, dari beberapa pendapat di atas yang dimaksud dengan pemberdayaan masyarakat adalah suatu proses bertahap yang harus di lakukan dalam rangka memperoleh serta meningkatkan daya sehingga masyarakat mampu mandiri.

Di samping itu, prinsip dasar yang digunakan dalam pemberdayaan masyarakat menurut Randy dan Riant, ${ }^{19}$ yaitu:

${ }^{17}$ Abdul Mujib dan Jusuf Mudzakir, Ilmu Pendidikan Islam, ..., Ibid, hlm. 36 .

${ }_{18}$ Ambar Teguh, Kemitraan dan Model-Model Pemberdayaan,..., Ibid, hlm. 77- 78 .

${ }^{19}$ Randy, R.W dan Riant, N.D, Manajement Pemberdayaan: Sebuah pengantar dan Panduan Untuk Pemberdayaan Masyarakat, ..., Ibid, hlm. 284. 
1. Good governance: keterbukaan, partisipasi, demokrasi, akuntabilitas.

2. Desentralisasi dan otonomi daerah.

3. Nilai-nilai universal: kerelaan, jujur, adil, kesetaraan gender.

4. Pembangunan berkelanjutan, sosial ekonomi, ekologi.

5. Masyarakat sebagai pelaku pembangunan.

6. Perencanaan partisipatif.

\section{PNPM Mandiri}

Yang dimaksud dengan istilah PNPM Mandiri yaitu program nasional dalam wujud kerangka kebijakan sebagai dasar dan acuan pelaksanaan program-program penanggulangan kemiskinan berbasis pemberdayaan masyarakat yang dilaksanakan melalui harmonisasi dan pengembangan sistem serta mekanisme dan prosedur program, penyediaan pendampingan dan pendanaan stimulan untuk mendorong prakarsa dan inovasi masyarakat dalam upaya penanggulangan kemiskinanyang berkelanjutan. ${ }^{20}$

Adapun tujuan pelaksanaan PNPM Mandiri program penanggulangan kemiskinan di perkotaan adalah:

1. Mewujudkan masyarakat "berdaya" dan "mandiri", yang mampu mengatasi berbagai persoalan kemiskinan di wilayahnya, sejalan dengan kebijakan Progran Nasional Pemberdayaan Masyarakat (PNPM) Mandiri.

2. Meningkatkan kapasitas pemerintah daerah dalam menerapkan model pembangunan partisipatif yang berbasis kemitraan dengan masyarakat dan kelompok peduli setempat.

3. Mewujudkan harmonisasi dan sinergi berbagai program pemberdayaan masyarakat untuk optimalisasi penanggulangan kemiskinan.

${ }^{20}$ http: / / www.pnpm_mandiri.org/index.php?option $=\mathrm{com}_{-}$ docman\&task $=$ cat_view\&gid $+51 \&$ Itemid $=46$. 
4. Meningkatkan capaian manfaat bagi masyarakat miskin untuk mendorong peningkatan IPM dan pencapaian sasaran MDGs. ${ }^{21}$

Mengingat bahwa Program penanggulangan kemiskinan di perkotaan adalah landasan dan pemicu tumbuhnya gerakan pembangunan berkelanjutan dalam penanggulangan kemiskinan di perkotaan, maka di perlukan rumusan visi dan misi yang jelas sehingga dapat di pakai sebagai acuan perilaku dan arahan bagi semua pelaku PNPM maupun bagi para pihak dalam mengembangkan program-program kemiskinan di wilayahnya.

1. Visi program penanggulangan kemiskinan di perkotaan: terwujudnya masyarakat madani, yang maju, mandiri, dan sejahtera dalam lingkungan permukiman sehat, produktif dan lestari.

2. Misi program penanggulangan kemiskinan di perkotaan: membangun masyarakat mandiri yang mampu menjalin kebersamaan dan sinergi dengan pemerintah maupun kelompok peduli setempat dalam menanggulangi kemiskinan secara efektif dan mampu mewujudkan terciptanya lingkungan permukiman yang tertata, sehat, produktif dan berkelanjutan. ${ }^{22}$

Dalam PNPM Mandiri program penanggulangan kemiskinan di perkotaan, proses pendampingan untuk pembelajaran dilakukan melalui tahapan yang di sebut dengan siklus PNPM program penanggulangan kemiskinan di perkotaan. ${ }^{23}$ Adapun siklusnya sebagai berikut:

1. Rembug Kesiapan Masyarakat

2. Refleksi Kemiskinan

${ }^{21}$ DPU DirJen, ,Panduan Diskusi Refleksi Kemiskinan, Jakarta: Cipta Karya, 2007, hlm. 2.

${ }^{22}$ DPU DirJen, Pedoman Teknis Pelaksanaan FGD Refleksi Kemiskinan, J karta: Cipta Karya, 2007, hlm. 6.

${ }^{23}$ DPU DirJen, Panduan Fasilitasi Rembug Kesiapan Masyarakat. Jakarta: Cipta Karya, 2007, hlm. 1. 
3. Pemetaan Swadaya

4. Membangun BKM (Badan Keswadayaan Masyarakat)

5. Pengembangan KSM (Kelompok Swadaya Masyarakat)

Seperti yang telah dikemukakan bahwa nilai-nilai pendidikan Islam adalah suatu seperangkat keyakinan atau perasaan dalam diri manusia yang sesuai dengan norma dan ajaran islam untuk menciptakan insan kamil (manusia sempurna).

Nilai-nilai tersebut terdiri dari tiga pilar utama, yaitu nilai itiqodiyah, nilai kbuluqiyah, dan nilai amaliyah. Setelah menganalisa penulis menemukan bahwa dalam PNPM Mandiri program penanggulangan kemiskinan di perkotaan memuat nilai-nilai pendidikan Islam, yaitu:

\section{Nilai I'tiqodiyah}

Nilai ini berkaitan dengan nilai akidah (keimanan) seperti telah dijelaskan sebelumnya bahwa penjabaran dari akidah ini biasa disebut dengan rukun iman, yakni mengenai keimanan kepada Allah, malaikat, rasul, kiamat dak takdir. Dalam PNPM mandiri program penanggulangan kemiskinan di perkotaan tidak terdapat/mengandung nilai i'tiqodiyah.

\section{Nilai Khuluqiyah}

Nilai khuluqiyah berkaitan dengan nilai akhlak, moral dan etika seperti telah di jelaskan sebelumnya bahwa akhlak adalah ajaran tentang hal yang baik dari hal yang buruk, yang menyangkut tingkah laku dan perbuatan manusia. Jika seseorang mempunyai tingkah laku dan perangai yang baik maka boleh dikatakan bahwa dia mempunyai akhlak yang baik, begitu sebaliknya jika seseorang mempunyai tingkah laku dan perangai yang buruk, maka boleh dikatakan bahwa dia mempunyai akhlak yang buruk.

Adapun nilai-nilai akhlak (khuluqiyah) yang terkandung dalam PNPM mandiri program penanggulangan kemiskinan 
di perkotaan terdapat dalam nilai universal kemanusiaan yaitu antara lain:

a. Jujur

Hal yang tercermin dalam pembangunan BKM, yang mana BKM sebagai dewan pimpinan kolektif bertanggungjawab untuk menggerakkan potensi warga masyarakat kelurahan untuk menanggulangi kemiskinan, oleh sebab itu mempunyai tugas untuk membangun modal sosial diwilayahnya. Modal sosial yang harus dibangun yaitu menumbuhkan kerjasama dan kepercayaan diantara anggota BKM, antara BKM dengan warga masyarakat, antar kelompok masyarakat, antara BKM, masyarakat dan pihak luar. Dalam proses ini keterbukaan dan kejujuran diantara anggota BKM merupakan unsur yang paling penting untuk bekerjasama. Dari uraian diatas jelas terlihat bahwa dalam pembangunan BKM mengajarkan kepada masyarakat untuk selalu berbuat jujur dalam setiap hal.

Islam sangat menjunjung tinggi kejujuran seperti dalam firman Allah Swt dalam Surat At Taubah ayat 119 disebutkan:

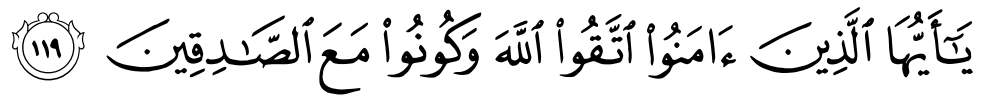

"Hai orang-orang yang beriman bertakwalah kepada Allah, dan hendaklah kamu bersama orang-orang yang benar."

Dalam hadist juga disebutkan:

'Dari Ibnu Mas'ud ra, dari nabi saw, beliau bersabda: Sesunggubnya kebenaran itu membawa kepada kebaikan dan kebaikan itu membawa ke surga. Seseorang akan selalu bertindak jujur sehingga ia ditulis disisi Allah sebagai orang jujur, dan sesunggubnya dusta itu membawa kepada kejahatan dan kejahatan itu membawa ke neraka. Seseorang akan selalu berdusta sehingga ia ditulis disisi Allah sebagai pendusta." (HR. Bukhori dan muslim). ${ }^{24}$

${ }^{24}$ Al-Imam Abu Zakaria Yahya Bin Syaraf An-Nawawi diterjemahkan Achmad Sunarto, Terjemahan Riyadhus Shalibin, Jakarta: Pustaka Amani, 1999, hlm. 79 . 
b. Dapat dipercaya (amanah)

Amanah merupakan salah satu sifat wajib nabi muhammad Saw., sifat mahmudah yang patut kita teladani sebagai seorang muslim, meskipun itu tidak mudah.

Dalam al Qur'an surat An Nisa ayat 58 diterangkan:

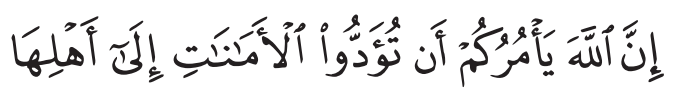

"Sesungguhnya Allah menyurub kamu menyampaikan amanat kepada yang berbak menerimanya."

Nilai amanah dalam program penanggulangan kemiskinan di perkotaan tercermin dalam:

1) Pembangunan BKM, seperti terlihat dalam ciri-ciri organisasi masyarakat warga yaitu membangun masyarakat saling percaya.

2) Pengembangan KSM, sikap saling percaya diantara anggota kelompok didasari dan dibangun dalam suasana keterbukaan, kejujuran, keikhlasan, saling menghargai, saling peduli, keadilan, dan nilai-nilai positif lainnya.

c. Ikhlas/Kerelawanan

Nilai ini ikhlas/kerelawanan ini tercermin dalam:

a. Pembangunan BKM, tiap anggota/warga terhimpun secara suka rela bukan karena terpaksa. Dengan demikian jelas bahwa setiap individu yang ingin menjadi anggota BKM benar-benar atas kemauannya sendiri.

b. RKM, dalam salah satu hasil yang diharapkan yaitu adanya relawan-relawan warga sebagai motor penggerak penanggulangan kemiskinan.

Berbuat ikhlas dalam segala hal merupakan anjuran ajaran islam, amal yang ikhlas adalah yang semata mata karena Allah 
tidak karena yang lainnya karena ikhlas sangat berkaitan dengan kerja hati seseorang. ${ }^{25}$

Hal ini terdapat dalam hadist disebutkan bahwa:

"Dari Abu Hurairah Abdurrahman bin Shakir ra, berkata: "Rasullulab saw bersabda": "Sesunggubnya Allah Ta'ala tidak melihat bentuk tububmu dan tidak pula melihat ketampananmu tetapi Allah melihat hatimu”. (HR. Muslim). ${ }^{26}$

\section{d. Adil}

Dalam menetapkan kebijakan dan melaksanakan program penanggulangan kemiskinan di perkotaan harus menekankan asas keadilan (fairness), kebutuhan nyata dan kepentingan masyarakat miskin. Nilai adil ini tercermin dalam:

a. Pengembangan BKM, dalam menjalankan tugas yang diamanahkan oleh masyarakat harus dikelola dengan jujur dan adil, di mana adil disini bukan berarti bagi rata tetapi menentukan priorotas berdasarkan kebutuhan nyata bukan untuk kepentingan pribadi.

b. Pengembangan KSM, dalam salah satu prinsipnya yaitu keadilan.dari kedua uraian di atas jelas terlihat bahwa program penanggulangan kemiskinan di perkotaan mengajarkan kepada masyarakat untuk berbuat adil.

Perintah untuk berlaku adil sesuai dengan firman Allah dalam Al Qur'an surat an Nahl ayat 90 dan Al Hujurat ayat 9.

Al Qur'an surat an Nahl ayat 90 berbunyi:

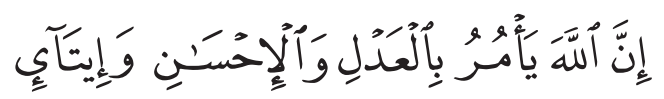

"Sesunggubnya Allah menyuruh (kamu) Berlaku adil dan berbuat kebajikan”. hlm. 37.

${ }^{25}$ Erwati Aziz, Prinsip-prinsip Pendidikan Islam. Solo: Tiga Serangkai, 2003,

${ }^{26}$ Al-Imam Abu Zakaria Yahya Bin Syaraf An-Nawawi diterjemahkan Achmad Sunarto, Terjemahan Riyadhus Shalibin, ..., Ibid, hlm. 7. 


\section{Nilai Amaliyah}

Nilai amaliyah yang terkandung dalam PNPM Mandiri program penanggulangan kemiskinan di perkotaan terdapat dalam nilai kemasyarakatan yaitu antara lain:

a. Kesetaraan

Nilai ini tercermin dalam:

1) Pembangunan BKM, dalam pembangunan BKM ini mengajarkan kepada masyarakat adanya kesetaraan di mana komunitas terbentuk sebagai himpunan warga yang setara.

2) Pengembangan KSM, salah satu prinsipnya adalah kesetaraan, semua anggota kelompok mempunyai hak dan kewajiban yang sama, tidak ada keistimewaan termasuk bagi para pengurus kelompok .

Hal ini sesuai dengan Al Qur'an surat Al hujurat ayat 13 yang berbunyi:

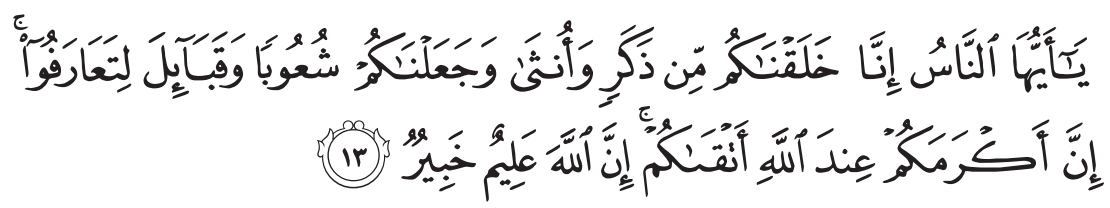

"Hai manusia, Sesunggubnya Kami menciptakan kamu dari seorang laki-laki dan seorang perempuan dan menjadikan kamu berbangsabangsa dan bersuku-suku supaya kamu saling kenal-mengenal. Sesunggubnya orang yang paling mulia diantara kamu di sisi Allah ialah orang yang paling taqwa diantara kamu. Sesunggubnya Allah Maha mengetahui lagi Maha Mengenal.”

Dari uraian tersebut terlihat jelas dengan adanya kesetaraan dalam masyarakat akan menjadikan masyarakat yang saling memiliki, tidak ada perbedaan dalam segala hal yang mana dalam ayat di atas juga diterangkan bahwa allah swt menjadikan umat-Nya bersuku-suku dan berbangsa-bangsa supaya saling mengenal. Dengan keadaan yang demikian maka akan tercipta suasana kehidupan yang nyaman dan damai.

b. Kesatuan dalam keberagamaan 
Kesatuan dalam keberagamaan ini sesuai dengan surat Al Hujurat ayat 13 yang menerangkan bahwa Allah menjadikan kita (manusia) berbangsa-bangsa dan bersuku-suku. Nilai ini tercermin dalam:

1. Pemetaan Swadaya, dalam pemetaan swadaya ini mengajarkan kepada masyarakat baik perempuan maupun laki-laki dapat menyadari persoalan kehidupan dalam lingkungan yang mereka hadapi, sehingga diharapkan terjadi pemahaman terhadap kondisi warga di lingkungannya.

2. Pembangunan BKM, mengajarkan kepada masyarakat warganya untuk selalu menghargai keragaman dan hak asasi manusia sebagai dasar membangun sinergi.

3. Refleksi kemiskinan, dalam salah satu tujuannya mengajarkan kepada masyarakat untuk mewujudkan rasa memiliki masyarakat miskin dan peduli masyarakat lainnya terhadap upaya-upaya penanggulangan kemiskinan.

\section{c. Demokrasi}

Nilai ini tercermin dalam pembangunan BKM, mengajarkan kepada masyarakat untuk menjunjung tinggi nilainilai demokrasi dalam setiap keputusan yang diambil secara intensif melakukan musyawarah.

Kemampuan masyarakat bermusyawarah yang dilandasi kesadaran kritis untuk senantiasa menuju kebaikan bersama, pada hakekatnya merupakan manifestasi tertinggi dari suatu kehidupan bermasyarakat, oleh karena itu program penanggulangan kemiskinan di perkotaan mendorong masyarakat agar dapat mengutamakan dan mendasarkan keputusan melalui mekanisme musyawarah agar mampu membangun dan memperkuat lembaga pimpinan kolektif masyarakat.

Islam mengajarkan untuk selalu bermusyawarah dalam setiap memecahkan suatu masalah. Hal ini dapat dilihat dalam al-Qur'an surat Ali Imran ayat 159: 


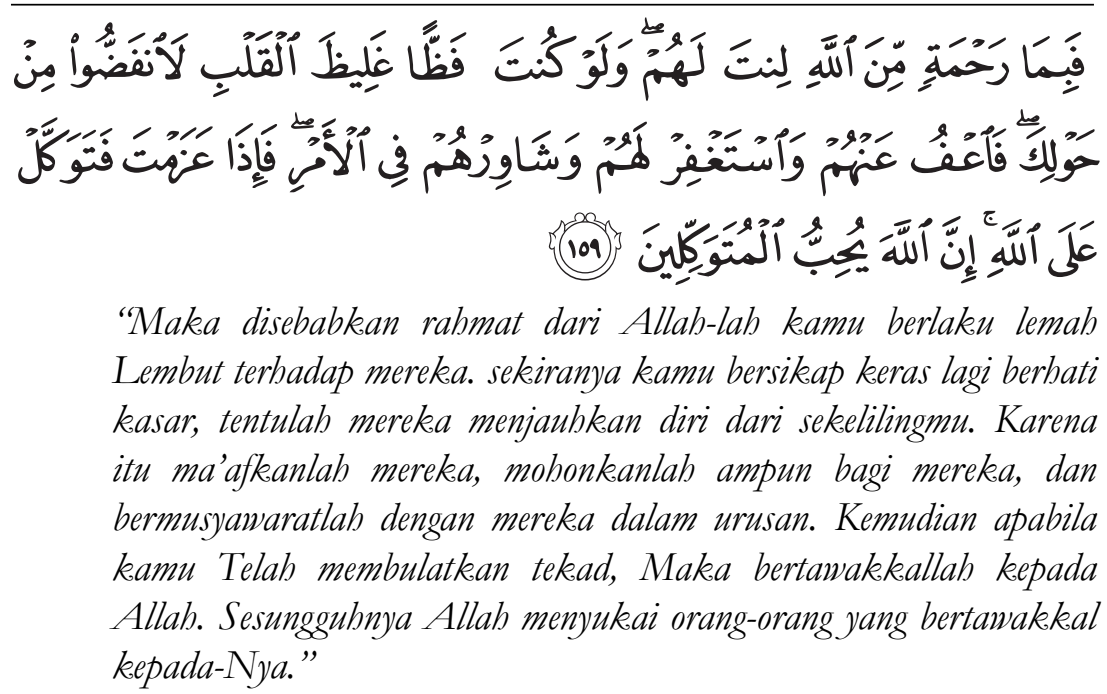

d. Transparansi

Dalam proses manajemen program maupun manajemen organisasi masyarakat harus menerapkan prinsip trasparansi, sehingga masyarakat belajar dan melembagakan sikap bertanggung jawab serta tanggung gugat terhadap pilihan keputusan dan kegiatan yang dilaksanakannya. Nilai ini tercermin dalam:

Pengembangan KSM, mengajarkan kepada masyarakat melalui salah satu prinsipnya yaitu saling mempercayai dan saling mendukung (keterbukaan). Dengan demikian diharapkan dapat mendorong para anggota untuk mengekspresikan gagasangagasan dan perasaannya dengan nyaman sehingga terhindar dari rasa saling curiga, fitnah, dan konflik-konflik di antara warga masyarakat.

Pelaksanaan dan pemantauan program, dalam pelaksanaan kegiatan diajarkan kepada masyarakat untuk membangun keterbukaan dan dapat dipertanggungjawabkan.

e. Partisipasi

Dalam tiap langkah kegiatan program penanggulangan kemiskinan di perkotaan harus dilakukan secara partisipatif 
sehingga mampu membangun rasa kepedulian dan kepemilikan serta proses belajar melalui bekerja sama.

Nilai ini terdapat dalam pengembangan KSM, yang mana mengajarkan kepada masyarakat melalui prinsipnya yaitu berpartisipasi nyata bahwa setiap anggota wajib berkontribusi kepada kelompok sebagai wujud komitmen dalam rangka keswadayaan serta ikatan kelompok.

Jadi pada dasarnya nilai-nilai tersebut (nilai kbuluqiyah dan amaliyah) yang terkandung dalam PNPM Mandiri program penanggulangan kemiskinan di perkotaan tercermin dalam siklus PNPM mandiri program penanggulangan kemiskinan di perkotaan. Dengan demikian jelas bahwa nilai-nilai yang diajarkan dalam program penanggulangan kemiskinan di perkotaan merupakan nilai dalam pemberdayaan masyarakat yaitu prinsip good governance dan prinsip nilai-nilai universal.

\section{Simpulan}

Setelah penulis mengadakan analisis terhadap PNPM Mandiri program penanggulangan kemiskinan di perkotaan, maka dapat disimpulkan bahwa dalam PNPM Mandiri program penanggulangan kemiskinan di perkotaan terdapat nilai-nilai pendidikan Islam, nilai-nilai yang diajarkan dalam PNPM Mandiri program penanggulangan kemiskinan di perkotaan adalah sebagai berikut:

1. Nilai Khuluqiyah:

a. Jujur, tercermin dalam pembangunan BKM.

b. Dapat dipercaya (amanah), tercermin dalam pembangunan BKM dan pengembangan KSM.

c. Ikhlas, tercermin dalam pembangunan BKM dan RKM.

d. Adil yang tercermin dalam pembangunan BKM dan pengembangan KSM. 
2. Nilai amaliyab:

a. Kesetaraan yang tercermin dalam pembangunan BKM dan pengembangan KSM.

b. Kesatuan dalam keberagamaan yang tercermin dalam pemetaan swadaya, pembangunan BKM, dan refleksi kemiskinan.

c. Demokrasi yang tercermin dalam pembangunan BKM.

d. Transparansi yang tercermin dalam pengembangan KSM dan pelaksanaan dan pemantauan program.

e. Partisipasi yang tercermin dalam pengembangan KSM. 


\section{Daftar Pustaka}

Ahmadi, Nor S, MKDU Dasar Dasar Pendidikan Agama Islam Untuk Perguruan Tinggi, Jakarta: Bumi Aksara, 1991.

Abdul Mujib dan Jusuf Mudzakir, Ilmu Pendidikan Islam, Jakarta: Kencana Prenada Media, 2006.

Al-Imam Abu Zakaria Yahya Bin Syaraf An-Nawawi diterjemahkan Achmad Sunarto, Terjemahan Riyadhus Shalihin, Jakarta: Pustaka Amani, 1999.

Arief, Armai, Pengantar ilmu dan metodologi pendidikan islam, Jakart: Ciputat Pers, 2002.

Arifin, H. M., Ilmu Pendidikan Islam Sekolab: Suatu Tinjauan Teoritis dan Praktis Berdasarkan Pendekatan Interdisipliner, Jakarta: Bumi Aksara, 2000.

Aziz, Erwati, Prinsip-prinsip Pendidikan Islam. Solo: Tiga Serangkai, 2003.

Crescent, Tim, Menuju Masyarakat Mandiri: Pengembangan Sistem Keterjaminan Sosial, Jakarta : PT. Gramedia Pustaka Utama, 2003.

CSIS, Pemberdayaan Masyarakat Lapis Bawah Center for setrategis and International Studies/ jurnal, 1997.

Daradjat, Zakiah, Ilmu Pendidikan Islam, Jakarta: Bumi Aksara, 2004, hlm. 19.

Darmadi, Hamid, Dasar konsep Pendidikan Moral, Landasan Konsep Dasar dan Implementasi, Bandung: Alfabeta, 2007.

DPU DirJen, Panduan Diskusi Refleksi Kemiskinan, Jakarta: Cipta Karya, 2007. 
, Panduan Fasilitasi Rembug Kesiapan Masyarakat. Jakarta: Cipta Karya, 2007.

- Pedoman Teknis Pelaksanaan FGD Refleksi Kemiskinan, Jakarta: Cipta Karya, 2007.

- Pedoman Umum P2KP 3, Jakarta: Cipta Karya, 2005.

, Petunjuk Pelaksanaan PNPM Mandiri P2KP, Jakarta: Cipta Karya, 2007.

Farihah, Irzum, "Strategi Dakwah Di Tengah Konflik Masyarakat", Jurnal Addin, Volume 8, Nomor 2, Agustus 2014.

http:/ / www.pnpm mandiri.org/index.php?option $=\mathrm{com}$ docman\&task $=$ cat view\&gid $+51 \&$ Itemid $=46$.

Jalaludin \& Abdullah Idi, Filsafat Pendidkan Manusia, Jogjakarta: Ar-Ruzz Media, 2007.

Moleong, Lexi, J., Metodologi Penelitian Kualitatif, Bandung: PT. Remaja Rosda Karya, 1999.

Randy, R.W dan Riant, N.D, Manajement Pemberdayaan: Sebuah pengantar dan Panduan Untuk Pemberdayaan Masyarakat, Jakarta: Elex Media Komputindo, 2007.

S, Ambar Teguh, Kemitraan dan Model Model Pemberdayaan, Yogyakarta: Gava Media, 2004

Sumodiningrat, Gunawan, Pemberdayaan Sosial, Jakarta: PT. Kompas Media Nusantara, 2007.

Usman, Sunyoto, Pembangunan dan Pemberdayaan Masyarakat, Yogyakarta : Pustaka Pelajar, 2008.

Zed Mestika, Metode Penelitian Kepustakaan, Jakarta: Yayasan Obor Indonesia, 2004. 